\title{
Cardiac Norepinephrine Stores in Experimental Heart Failure in the Dog*
}

\author{
Charles A. Chidsey, Gerard A. Kaiser, Edmund H. Sonnenblick, \\ James F. Spann, and Eugene Braunwald \\ (From the Cardiology Branch, National Heart Institute, Bethesda, Md.)
}

Although the underlying basis for the defective myocardial function characteristic of congestive heart failure has not been defined, the contractile state of the myocardium is known to be influenced by a number of determinants $(1,2)$, and an abnormality of any one of them could be a factor contributing to the defective performance of the failing heart. Prominent among the determinants of myocardial function is the activity of the sympathetic nervous system. Sympathetic activity has been shown to have an important influence on the heart, particularly in circumstances in which an imbalance or potential imbalance exists between the cardiac output and the perfusion requirements of the peripheral tissues (3-5). In patients with congestive heart failure alterations in the cardiovascular system have been observed which have suggested that increased sympathetic or adrenal medullary activity may be present in this state. For example, vasoconstriction of the splanchnic and renal vascular beds and augmentation of peripheral venous tone have been observed in heart failure $(6-10)$. The view that these changes result from increased sympathetic activity is supported by the finding of an elevated urinary excretion of norepinephrine $(11,12)$ and by the observation that circulating norepinephrine rises to abnormally high levels during exercise in such patients (13). Furthermore, sympathetic blockade with hexamethonium has been found to reduce the elevated venous tone in heart failure (14).

The recent finding of diminished norepinephrine concentration in the atria of some patients with heart failure suggested the possibility that a depletion of the neurotransmitter store in the heart may occur in this condition, resulting in an interference with the activity of the cardiac sym-

* Submitted for publication July 13, 1964; accepted August 28, 1964. pathetic nerves (15). In order to determine whether such a depletion does in fact occur, it appeared necessary to measure the total norepinephrine contained in the heart. Accordingly, heart failure was produced in dogs, and the cardiac stores of norepinephrine were assessed both chemically and pharmacologically. It has been shown in the present investigation that the norepinephrine in the heart is markedly reduced in experimental heart failure. The magnitude of this reduction is reflected not only by the change in tissue norepinephrine content but also by a virtual absence of a contractile response of the myocardium to tyramine, a sympathomimetic amine that acts by releasing norepinephrine (16).

\section{Methods}

Heart failure was produced in eight dogs by the technique described by Barger, Roe, and Richardson (17) and also used by Davis, Trapasso, and Yankopoulos (18). Tricuspid insufficiency was induced by excising one or two leaflets of the tricuspid valve through a right atriotomy under direct vision after temporary caval occlusion. Seven to 10 days later, a band of ceramic beads wrapped in ivalon was placed about the main pulmonary artery just above the pulmonic valve. Leads from this band were brought out through the left chest wall, permitting later constriction. Seven days after placing the band it was constricted sufficiently to elevate the central venous pressure to values in excess of 200 $\mathrm{mm} \mathrm{H}_{2} \mathrm{O}$. The dogs were then maintained on standard diets for the next 6 to 8 weeks. Neither digitalis nor diuretic therapy was given to any of the animals. In order to determine the effect of the operative procedure itself upon myocardial norepinephrine levels, sham operations were carried out in six dogs; a right atriotomy was performed without damage to the tricuspid valve, and 7 to 10 days later the base of the main pulmonary artery was dissected free, but no band was placed around it. In addition, one dog with naturally occurring severe congestive heart failure due to mitral regurgitation was studied, as well as one animal in which the inferior vena cava was ligated above the entrance of the hepatic veins by the technique of Davis and Howell (19). 
Under pentobarbital anesthesia, the animals were sacrificed 6 to 8 weeks after constricting the band around the pulmonary artery by removing the heart, which was immediately placed in crushed ice and dissected. In addition, the heart was obtained by a similar method in 10 control dogs, the animal with naturally occurring heart failure, and the dog with inferior vena caval constriction. After the atria were removed, the free wall of the right ventricle was dissected from the septum and left ventricle. The right ventricle, and the left ventricle with the septum, were analyzed separately. Atrial tissue was removed from the control dogs and from five of the eight dogs with congestive heart failure. Tissues were homogenized immediately in the cold with 10 vol of $5 \%$ trichloroacetic acid in a Virtis homogenizer. After centrifugation at $20,000 \times g$ at $4^{\circ} \mathrm{C}$ for $20 \mathrm{~min}$ utes, a clear supernatant fluid was used for adsorption on aluminum oxide at $\mathrm{pH}=8.4$ (20). Catecholamines were eluted from the aluminum oxide with $0.2 \mathrm{~N}$ acetic acid and measured in an Aminco-Bowman spectrophotofluorometer after oxidation to the trihydroxyindole with ferricyanide at $\mathrm{pH}=6.1(21,22)$. Readings were made at activation wave lengths of 390 and 425 and fluorescence wave lengths of 500 and 525 , which allowed for the differentiation of both norepinephrine and epinephrine. The concentration of norepinephrine was determined, and from this value and the weight of the ventricle the total amount of norepinephrine in the ventricle was calculated; this value was also expressed as total ventricular norepinephrine per kilogram of body weight, using the preoperative weights in the dogs that had undergone operation. Recoveries of norepinephrine added to tissue samples averaged $88.5 \%$, and the results were not corrected for this recovery. In order to estimate the precision of the norepinephrine measurement, duplicate analyses were performed on 21 specimens, and the standard deviation of the measurement, based on these duplicate analyses, was determined to be $0.06 \mu \mathrm{g}$ per $\mathrm{g}$.

In 12 dogs the uptake and binding of DL-norepinephrine- $7-\mathrm{H}^{3} 1$ was evaluated. The specific activity of this material was $77.2 \mu \mathrm{c}$ per $\mu \mathrm{g}$, and its activity was demonstrated to be present only in norepinephrine by paper chromatography and by comparison of recovery of radioactivity and carrier norepinephrine after isolation, using both aluminum oxide and Dowex $50\left(\mathrm{H}^{+}\right)$resin. A tracer dose of $1 \mu \mathrm{c}$ per $\mathrm{kg}$ was administered intravenously over 2 minutes to six control dogs and six dogs with congestive heart failure. One hour later the dogs were sacrificed, the hearts removed, and an aluminum oxide eluate was prepared as described above. A portion of this eluate was placed in a counting vial, lyophilized, redissolved in $0.2 \mathrm{ml}$ distilled water, mixed with $10 \mathrm{ml}$ of counting solution (23), and counted in a liquid scintillation spectrometer. The efficiency of this system was approximately $20 \%$, and internal standards were added to all samples. Sufficient counts were obtained to maintain a standard deviation of counting below $2 \%$. In order to estimate the precision of the radioactive

\footnotetext{
${ }^{1}$ New England Nuclear Corp., Boston, Mass.
}

measurement, duplicate analyses were performed on 11 specimens, and the standard deviation of the measurement, based on these duplicate analyses, was determined to be $0.15 \mathrm{~m} \mu \mathrm{c}$ per $\mathrm{g}$.

The contractile responses to tyramine and norepinephrine of papillary muscles were studied in vitro in muscles obtained from three of the control dogs, from three of the sham-operated animals, from five of the dogs with experimental congestive heart failure, and from the animal with naturally occurring heart failure. After removal of the heart as described above, one or two papillary muscles were excised from the right ventricle and mounted in myographs where they were bathed in $10 \mathrm{ml}$ of Krebs' solution oxygenated with $95 \% \mathrm{O}_{2}$ and $5 \% \mathrm{CO}_{2}$ at $30^{\circ} \mathrm{C}$, as previously described (24). Constant muscle length was maintained and isometric force was recorded during stimulation at 12 impulses per minute with a Grass stimulator. Tyramine was always added first in $0.1-\mathrm{ml}$ vol to achieve concentrations in the

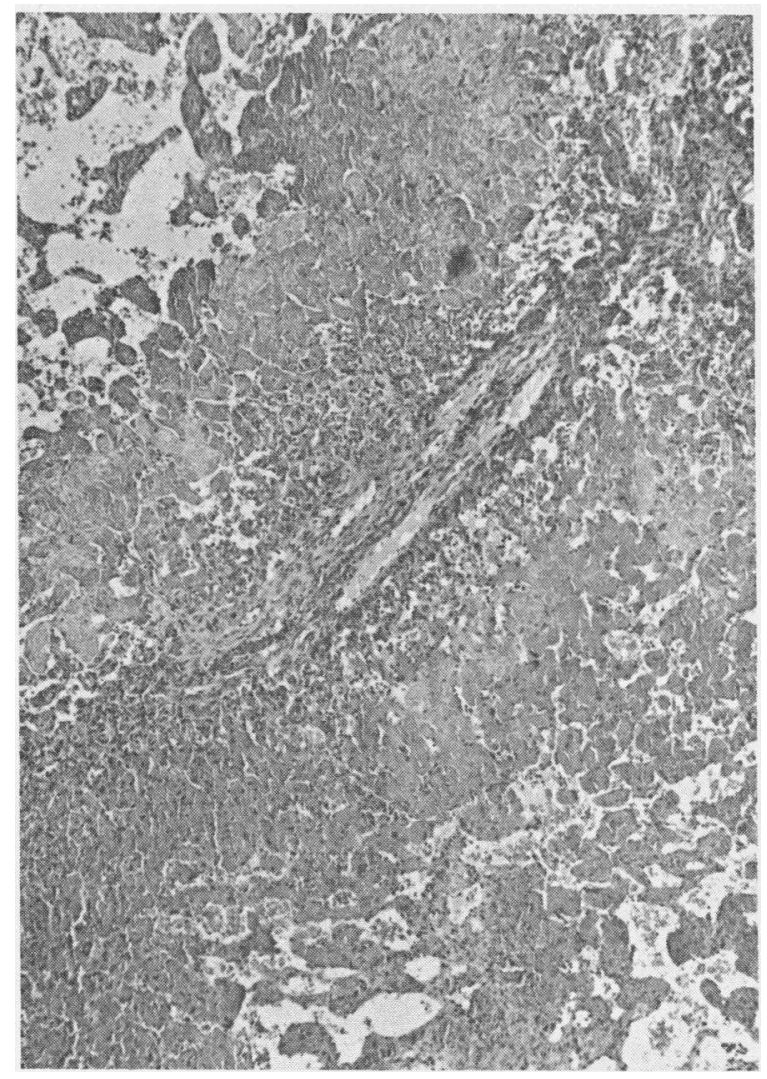

Fig. 1. Photomicrograph OF the Liver of A Dog WITH EXPERIMENTAL HEART FAILURE $(F-6)$. A hepatic triad is present in the center, surrounded by a few normally appearing hepatic cells. Peripherally there is necrosis and actual disappearance of hepatic cells. The latter are replaced by dilated sinusoids, which in some areas form actual lakes of red blood cells. There is cellular infiltration of the hepatic triad and fibrosis, confirmed on trichrome stain. 
bath ranging from $10^{-7}$ to $10^{-8} \mathrm{M}$ (free base), and the responses were observed for 5 minutes after each addition. After the tyramine additions, the fluid was changed 3 times during 30 minutes, and the same procedure was repeated with norepinephrine using concentrations between $10^{-8}$ and $10^{-4} \mathrm{M}$.

\section{Results}

1) Pathology. Clinical and pathological evidence of right heart failure was present in all eight animals when they were sacrificed 6 to 8 weeks after the production of tricuspid insuffciency and pulmonic stenosis. Pleural and ascitic fluid was present in all animals. The livers were distended by severe venous congestion, and histologic study revealed engorgement of the sinusoids with blood, atrophy of the parenchymal cells, and fibrosis (Figure 1). The weights of the right ventricles were increased (Table I), averaging $2.02 \mathrm{~g}$ per $\mathrm{kg}$ compared to $1.65 \mathrm{~g}$ per $\mathrm{kg}$ in control animals $(p<0.01)$, whereas the weights of the left ventricles were decreased, averaging 3.64 $\mathrm{g}$ per $\mathrm{kg}$ compared to $4.77 \mathrm{~g}$ per $\mathrm{kg}$ in the control animals $(\mathrm{p}<0.01)$.

2) Tissue norepinephrine. In the control dogs the norepinephrine concentration averaged 0.84 and $0.86 \mu \mathrm{g}$ per $\mathrm{g}$, respectively, in the right and left ventricles, and no significant difference was observed in the sham-operated animals (Table II). However, the concentrations in the dogs with
TABLE I

Ventricular weights in dogs with congestive heart failure and in control dogs

\begin{tabular}{lrrrrr}
\hline \hline \multicolumn{1}{c}{ Dog } & $\begin{array}{c}\text { Body } \\
\text { weight }\end{array}$ & \multicolumn{2}{c}{ Right ventricle } & \multicolumn{2}{c}{ Left ventricle } \\
\hline \multicolumn{7}{c}{$k g$} & $g$ & $g / k g$ & $g$ & $g / k g$ \\
\multicolumn{7}{c}{ Control group } \\
Average (23)* & 14.7 & 23.9 & 1.65 & 69.6 & 4.77 \\
SD & 4.2 & 6.5 & 0.24 & 19.0 & 0.50 \\
\multicolumn{7}{c}{ Failure group } \\
Average (8) & 19.2 & 38.0 & 2.02 & 68.4 & 3.64 \\
SD & 2.2 & 6.9 & 0.46 & 13.6 & 0.97 \\
\hline
\end{tabular}

* Number of animals in each group.

congestive heart failure were reduced to less than one-fifth of the control, averaging 0.07 and 0.18 $\mu \mathrm{g}$ per $\mathrm{g}$, respectively, values significantly lower than those of either the control or the sham-operated groups $(p<0.01)$. The total quantity of norepinephrine in the ventricles was also significantly reduced in the dogs with congestive heart failure, averaging 0.14 and $0.63 \mu \mathrm{g}$ per $\mathrm{kg}$ of body weight, respectively, in the right and left ventricles compared to 1.14 and $3.89 \mu \mathrm{g}$ per $\mathrm{kg}$ of body weight in the control dogs and 1.17 and 3.78 $\mu \mathrm{g}$ per $\mathrm{kg}$ of body weight in the sham-operated animals. The norepinephrine in atrial tissue of the dogs with heart failure averaged $0.47 \mu \mathrm{g}$ per $\mathrm{g}$ $(\mathrm{SD}=0.50)$, a value that is significantly lower

TABLE II

Concentrations and total quantity of

\begin{tabular}{|c|c|c|c|c|c|c|c|c|c|c|}
\hline \multirow[b]{3}{*}{ Dog } & \multicolumn{6}{|c|}{ Control group } & \multirow[b]{3}{*}{ Dog } & \multirow{2}{*}{\multicolumn{3}{|c|}{$\frac{\text { Sham-operated group }}{\text { Right ventricle }}$}} \\
\hline & \multicolumn{3}{|c|}{ Right ventricle } & \multicolumn{3}{|c|}{ Left ventricle } & & & & \\
\hline & $\begin{array}{l}\text { NE* } \\
\text { conc. }\end{array}$ & $\begin{array}{c}\mathrm{NE} \\
\text { total }\end{array}$ & $\underset{\text { total }}{\mathrm{NE}}$ & $\begin{array}{c}\mathrm{NE} \\
\text { conc. }\end{array}$ & $\underset{\text { total }}{\mathrm{NE}}$ & $\underset{\text { total }}{\mathrm{NE}}$ & & $\begin{array}{l}\mathrm{NE} \\
\text { conc. }\end{array}$ & $\underset{\text { total }}{\mathrm{NE}}$ & $\begin{array}{c}\mathrm{NE} \\
\text { total }\end{array}$ \\
\hline $\begin{array}{l}\text { C- } 1 \\
\text { C- } 2 \\
\text { C- } 3 \\
\text { C- } 4 \\
\text { C- } 5 \\
\text { C- } 6 \\
\text { C- } 7 \\
\text { C- } 8 \\
\text { C- } 9 \\
\text { C- } 10\end{array}$ & $\begin{array}{l}\mu g / g \\
1.33 \\
0.52 \\
0.77 \\
1.12 \\
1.04 \\
1.04 \\
0.59 \\
0.52 \\
0.70 \\
0.76\end{array}$ & $\begin{array}{c}\mu g \\
41.6 \\
15.9 \\
24.7 \\
22.5 \\
16.0 \\
17.6 \\
7.0 \\
10.1 \\
13.0 \\
17.0\end{array}$ & $\begin{array}{c}\mu g / k g \dagger \\
1.95 \\
0.80 \\
1.26 \\
0.74 \\
1.23 \\
1.45 \\
0.73 \\
0.96 \\
1.00 \\
1.28\end{array}$ & $\begin{array}{l}\mu g / g \\
1.16 \\
0.62 \\
0.73 \\
1.06 \\
0.98 \\
0.96 \\
0.58 \\
0.65 \\
0.97 \\
0.85\end{array}$ & $\begin{array}{c}\mu g \\
118.6 \\
51.5 \\
62.7 \\
62.1 \\
46.1 \\
49.1 \\
26.5 \\
36.1 \\
63.1 \\
54.2\end{array}$ & $\begin{array}{c}\mu g / \mathrm{kg} \\
5.55 \\
2.62 \\
3.26 \\
4.78 \\
3.54 \\
4.02 \\
2.73 \\
3.40 \\
4.85 \\
4.11\end{array}$ & $\begin{array}{l}\text { S-1 } \\
\text { S-2 } \\
\text { S-3 } \\
\text { S-4 }\end{array}$ & $\begin{array}{c}\mu g / g \\
0.58 \\
0.90 \\
0.86 \\
0.72\end{array}$ & $\begin{array}{c}\mu g \\
17.7 \\
30.2 \\
23.7 \\
15.3\end{array}$ & $\begin{array}{l}\mu g / \mathrm{kg} \\
0.93 \\
1.36 \\
1.49 \\
0.91\end{array}$ \\
\hline $\begin{array}{c}\text { Average } \\
\text { SD } \\
\text { pł } \\
\text { p\& }\end{array}$ & $\begin{array}{l}0.84 \\
0.28\end{array}$ & $\begin{array}{r}18.5 \\
9.6\end{array}$ & $\begin{array}{l}1.14 \\
0.38\end{array}$ & $\begin{array}{l}0.86 \\
0.20\end{array}$ & $\begin{array}{l}57.0 \\
24.7\end{array}$ & $\begin{array}{l}3.89 \\
0.96\end{array}$ & & $\begin{array}{r}0.77 \\
0.15 \\
>0.10\end{array}$ & $\begin{array}{r}21.7 \\
6.6 \\
>0.10\end{array}$ & $\begin{array}{r}1.17 \\
0.30 \\
>0.10\end{array}$ \\
\hline
\end{tabular}

* $\mathrm{NE}=$ norepinephrine.

$\dagger$ Micrograms per kilogram of body weight. $\ddagger$ Compared to control group.

$\$$ Compared to sham-operated group. 
than that observed in 19 control dogs, $2.24 \mu \mathrm{g}$ per $\mathrm{g}(\mathrm{SD}=0.62) \quad(\mathrm{p}<0.01)$. In the $\operatorname{dog}$ with naturally occurring heart failure due to mitral insufficiency the norepinephrine concentration in the right and left ventricles was 0.21 and $0.16 \mu \mathrm{g}$ per $\mathrm{g}$, and the total norepinephrine in the ventricles was 0.28 and $0.95 \mu \mathrm{g}$ per $\mathrm{kg}$ of body weight. In the dog with inferior vena caval ligation the concentration of norepinephrine was normal, $1.03 \mu \mathrm{g}$ per $\mathrm{g}$ in the right ventricle and $0.94 \mu \mathrm{g}$ per $\mathrm{g}$ in the left ventricle.

The results of the epinephrine determinations revealed that the hearts obtained from the control animals contained amounts of epinephrine that were less than $10 \%$ of the norepinephrine present. Thus, these values were so low that the accuracy of the determination does not justify presentation of the data in a more quantitative manner. No increase in cardiac epinephrine, however, was observed in the tissues obtained from the animals with heart failure.

3) Uptake and intraneuronal binding of radioactive norepinephrine. One hour after the administration of $1 \mu \mathrm{c}$ per $\mathrm{kg}$ of tritium-labeled DL-norepinephrine, the activity of norepinephrine in the ventricles was determined in six control dogs and in six with experimental congestive heart failure. No defect in uptake or binding of the radioactive norepinephrine was observed, since

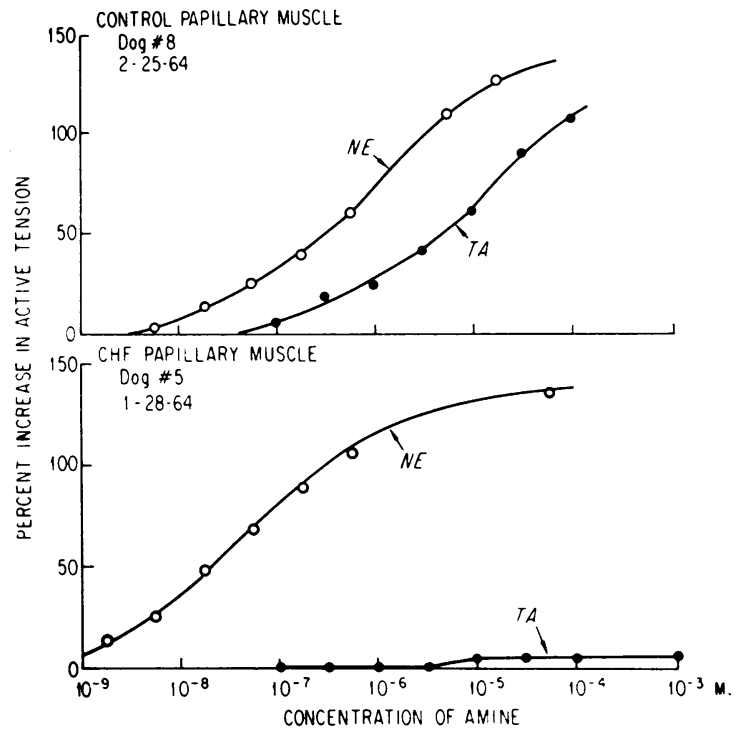

Fig. 2. Response curves to NoRepinephrine (NE) AND TO TYRAMINE (TA) IN PAPILLARY II TCLES OBTAINED FROM A CONTROL DOG (upper panel) AND A DOG WITH EXPERIMENTAL FAILURE (lower panel). The increases of active tension are plotted as per cent of the control active tension. The concentrations of amines are given as moles of free base per liter.

the total amount was not significantly lower in the ventricles of the dogs with congestive heart failure than in the control animals (Table III). Thus, the amount of radioactive norepinephrine bound in the heart, in relation to the endogenous nor-

TABLE II

norepinephrine in the canine ventricle

\begin{tabular}{|c|c|c|c|c|c|c|c|c|c|}
\hline \multirow{2}{*}{\multicolumn{3}{|c|}{$\frac{\text { Sham-operated group }}{\text { Left ventricle }}$}} & \multirow[b]{3}{*}{ Dog } & \multicolumn{6}{|c|}{ Failure group } \\
\hline & & & & \multicolumn{3}{|c|}{ Right ventricle } & \multicolumn{3}{|c|}{ Left ventricle } \\
\hline $\begin{array}{c}\mathrm{NE} \\
\text { conc. }\end{array}$ & $\begin{array}{l}\mathrm{NE} \\
\text { total }\end{array}$ & $\begin{array}{c}\mathrm{NE} \\
\text { total }\end{array}$ & & $\begin{array}{l}\mathrm{NE} \\
\text { conc. }\end{array}$ & $\underset{\text { total }}{\mathrm{NE}}$ & $\begin{array}{l}\mathrm{NE} \\
\text { total }\end{array}$ & $\begin{array}{l}\mathrm{NE} \\
\text { conc. }\end{array}$ & $\begin{array}{l}\mathrm{NE} \\
\text { total }\end{array}$ & $\begin{array}{l}\mathrm{NE} \\
\text { total }\end{array}$ \\
\hline $\begin{array}{l}\mu g / g \\
0.89 \\
1.00 \\
0.96 \\
0.62\end{array}$ & $\begin{array}{c}\mu g \\
71.4 \\
93.6 \\
79.8 \\
37.0\end{array}$ & $\begin{array}{c}\mu g / \mathrm{kg} \\
3.74 \\
4.17 \\
5.02 \\
2.20\end{array}$ & $\begin{array}{l}\text { F-1 } \\
\text { F-2 } \\
\text { F-3 } \\
\text { F-4 } \\
\text { F-5 } \\
\text { F-6 } \\
\text { F-7 } \\
\text { F-8 }\end{array}$ & $\begin{array}{c}\mu g / g \\
0.07 \\
0.02 \\
0.04 \\
0.05 \\
0.04 \\
0.07 \\
0.09 \\
0.18\end{array}$ & $\begin{array}{r}\mu g \\
2.1 \\
0.9 \\
1.2 \\
2.4 \\
1.3 \\
3.0 \\
3.1 \\
7.3\end{array}$ & $\begin{array}{c}\mu g / \mathrm{kg} \\
0.09 \\
0.05 \\
0.06 \\
0.11 \\
0.07 \\
0.16 \\
0.17 \\
0.48\end{array}$ & $\begin{array}{c}\mu g / g \\
0.14 \\
0.02 \\
0.08 \\
0.25 \\
0.10 \\
0.20 \\
0.36 \\
0.25\end{array}$ & $\begin{array}{r}\mu g \\
9.1 \\
1.7 \\
3.6 \\
20.2 \\
6.6 \\
14.0 \\
19.7 \\
19.8\end{array}$ & $\begin{array}{c}\mu g / \mathrm{kg} \\
0.40 \\
0.09 \\
0.17 \\
0.04 \\
0.36 \\
0.74 \\
1.08 \\
1.29\end{array}$ \\
\hline $\begin{array}{r}0.87 \\
0.17 \\
>0.10\end{array}$ & $\begin{array}{c}70.2 \\
23.8 \\
>0.10\end{array}$ & $\begin{array}{r}3.78 \\
1.18 \\
>0.10\end{array}$ & & $\begin{array}{r}0.07 \\
0.05 \\
<0.01 \\
<0.01\end{array}$ & $\begin{aligned} & 2.7 \\
& 2.1 \\
&< 0.01 \\
&< 0.01\end{aligned}$ & $\begin{array}{r}0.14 \\
0.05 \\
<0.01 \\
<0.01\end{array}$ & $\begin{array}{r}0.18 \\
0.11 \\
<0.01 \\
<0.01\end{array}$ & $\begin{array}{c}11.9 \\
7.6 \\
<0.01 \\
<0.01\end{array}$ & $\begin{array}{r}0.63 \\
0.44 \\
<0.01 \\
<0.01\end{array}$ \\
\hline
\end{tabular}


TABLE III

Uptake and binding of DL-norepinephrine-7- $H^{3}(1 \mu \mathrm{c} / \mathrm{kg})$ in the canine ventricle

\begin{tabular}{|c|c|c|c|c|c|c|}
\hline \multirow[b]{2}{*}{ Dog } & \multicolumn{3}{|c|}{ Right ventricle } & \multicolumn{3}{|c|}{ Left ventricle } \\
\hline & $\begin{array}{l}\mathrm{H}^{3} \mathrm{NE} \\
\text { conc.* }\end{array}$ & $\underset{\text { total }}{\mathrm{H}^{3} \mathrm{NE}}$ & $\begin{array}{l}\mathrm{H}^{8} \mathrm{NE} \\
\text { total }\end{array}$ & $\begin{array}{l}\mathrm{H}^{3} \mathrm{NE} \\
\text { conc. }\end{array}$ & $\begin{array}{l}\mathrm{H}^{3} \mathrm{NE} \\
\text { total }\end{array}$ & $\begin{array}{l}\mathrm{H}^{3} \mathrm{NE} \\
\text { total }\end{array}$ \\
\hline \multicolumn{7}{|c|}{$\begin{array}{l}m \mu c \quad m \mu c / k g \dagger \\
\text { Control group }\end{array}$} \\
\hline $\begin{array}{l}\text { Average of } 6 \text { exp. } \\
\text { SD }\end{array}$ & $\begin{array}{l}2.14 \\
0.81\end{array}$ & $\begin{array}{l}37.5 \\
17.5\end{array}$ & $\begin{array}{l}3.06 \\
0.47\end{array}$ & $\begin{array}{l}2.37 \\
0.44\end{array}$ & $\begin{array}{r}130.9 \\
39.2\end{array}$ & $\begin{array}{r}10.92 \\
1.63\end{array}$ \\
\hline \multicolumn{7}{|c|}{ Failure group } \\
\hline $\begin{array}{l}\text { Average of } 6 \text { exp. } \\
\text { SD }\end{array}$ & $\begin{array}{l}1.00 \\
0.67\end{array}$ & $\begin{array}{l}41.12 \\
37.9\end{array}$ & $\begin{array}{l}2.16 \\
0.75\end{array}$ & $\begin{array}{l}2.01 \\
1.12\end{array}$ & $\begin{array}{r}143.8 \\
83.6\end{array}$ & $\begin{array}{l}7.90 \\
4.80\end{array}$ \\
\hline
\end{tabular}

${ }^{*} \mathrm{H}^{3} \mathrm{NE}=$ tritium-labeled norepinephrine.

$\dagger$ Millimicrocuries per kilogram of body weight.

epinephrine present, was increased; the specific activity in the hearts of the dogs with congestive heart failure averaged $11.6(4.7) \mathrm{m} \mu \mathrm{c}$ per $\mu \mathrm{g}$ compared to $2.0(0.7) \mathrm{m} \mu \mathrm{c}$ per $\mu \mathrm{g}$ in the hearts of the control animals $(\mathrm{p}<0.01)$.

4) Contractile responses of isolated papillary muscles. The contractile responses to tyramine of papillary muscles obtained from dogs with and without congestive heart failure differed strikingly (Figure 2). In the muscles from the control dogs and the sham-operated animals the maximal increases in active tension, which averaged 138 and $116 \%$ of control, were produced by $10^{-4} \mathrm{M}$ tyramine, whereas the threshold doses ranged from $10^{-7}$ to $10^{-5} \mathrm{M}$ tyramine (Table IV). The muscles prepared from dogs with congestive heart failure exhibited maximal increases in active tension that averaged only $19 \%$ of control with a concentration of $10^{-3} \mathrm{M}$ tyramine, whereas the threshold concentrations ranged from $10^{-5}$ to $10^{-3}$

TABLE IV

Responses of isolated papillary muscles of the canine right ventricle to tyramine

\begin{tabular}{|c|c|c|c|c|c|}
\hline \multirow[b]{2}{*}{ Group } & \multirow{2}{*}{\multicolumn{2}{|c|}{$\begin{array}{c}\text { No. } \\
\begin{array}{c}\text { No. } \\
\text { of } \\
\text { of } \\
\text { dogs cles* }\end{array}\end{array}$}} & \multirow{2}{*}{$\begin{array}{l}\text { Threshold } \dagger \\
\left(\times 10^{-6} \mathbf{M}\right)\end{array}$} & \multicolumn{2}{|c|}{$\begin{array}{l}\text { Maximal } \\
\text { response }\end{array}$} \\
\hline & & & & Average & Range \\
\hline & & & & $\%$ & $\%$ \\
\hline Control & 3 & 4 & 0.1 to 3 & 138 & $91-183$ \\
\hline Sham-operated & 3 & 5 & 0.3 to 10 & 116 & $53-270$ \\
\hline Failure & 5 & 7 & 10 to 1,000 & 19 & $5-44$ \\
\hline
\end{tabular}

* In some animals two papillary muscles were removed and studied.

$\dagger$ Threshold represents concentration of tyramine at which the first detectable increase in active tension was observed.
$M$ tyramine. In order to determine that these muscles were capable of responding to norepinephrine, after tyramine, additions of norepinephrine to the bath were made in muscles from four of the five animals with heart failure. A large increase in active tension was observed in all of them, as shown by the example in Figure 2.

An attempt was made to replete the norepinephrine content of the papillary muscles from the dogs with congestive heart failure by adding large quantities of norepinephrine to the bath $\left(10^{-4} \mathrm{M}\right)$. After tissues were treated in this manner for 10 minutes and then washed 3 times during a 30 minute period to remove unbound norepinephrine, no increases in response to added tyramine were observed. Thus, the binding of sufficient catecholamine to restore the tyramine response was not achieved in vitro in this manner.

\section{Discussion}

The finding that the concentration of norepinephrine in atrial tissue of some patients with congestive heart failure was markedly reduced led to the suggestion that depletion of cardiac norepinephrine stores may occur in this state (15). Considerable caution, however, was necessary in the interpretation of these findings. The tissue that was analyzed was a small sample of a greatly enlarged atrium, and simple dispersion of sympathetic nerves in this enlarged chamber could not be excluded. Accordingly, to study this problem further, primary attention had to be directed to the ventricles rather than the atria, and determination of the total quantity of norepinephrine, as well as its concentration, was necessary. 
These considerations led to the present investigation, in which it was shown that experimental congestive heart failure is associated with a profound reduction of the norepinephrine stores in the ventricles. It is now clear that the low concentrations of norepinephrine found in the ventricles in experimental canine heart failure reflect a true reduction of myocardial norepinephrine stores and are not simply the result of a dilution of sympathetic nerve fibers by hypertrophied myocardial tissue. The changes observed in these animals with right-sided heart failure were marked, and the total norepinephrine content in both the right and left ventricles was reduced to values less than $20 \%$ of normal. This reduction in cardiac norepinephrine stores was generalized and involved the atria as well as the ventricles. Preliminary observations in the guinea pig with heart failure produced by aortic constriction have also revealed reductions in the cardiac norepinephrine stores (25). Thus, norepinephrine depletion in cardiac tissue has now been noted in congestive heart failure in three different species and appears to be independent of the location or precise nature of the intervention interfering with cardiac function.

The reduction of norepinephrine stores in the heart of dogs with heart failure was found to be of such a degree that the response to tyramine, which acts by releasing norepinephrine, was virtually absent in the isolated papillary muscle. Since the increase of active tension produced by the addition of norepinephrine to these muscles was of the same magnitude as that observed in muscles obtained from control and sham-operated dogs, it is concluded that there is no interference with the ability of the contractile elements to be affected by the catecholamine. The absence of a contractile response to tyramine observed in this study is evidence, albeit indirect, of the very significant reduction of norepinephrine stores that occurred in the failing heart. Indeed, Crout, Muskus, and Trendelenburg found that the chronotropic response of the guinea pig atrium to tyramine is almost normal in the presence of only a small faction of the normal neurotransmitter store (26).

Although it has been possible in experiments carried out both in vitro (26) and in vivo (27, 28 ) to restore, with norepinephrine, the response to tyramine, in vitro restoration of the contractile response has not been specifically studied in the papillary muscle from reserpinized dogs. In the present study it was not possible to restore the response of the isolated papillary muscle to tyramine by exposing it to norepinephrine. This finding suggests that the nature of the reduction of norepinephrine in heart failure differs in a fundamental from that which results from reserpine administration and that there may be a more profound interference with the binding of norepinephrine in heart failure. When uptake and binding were examined in the intact animal, however, no significant decrease in the retention of a tracer amount of radioactive norepinephrine was observed in the heart. Although the results of these two methods of evaluating norepinephrine uptake appear to be contradictory, the binding of minute quantities of exogenous norepinephrine in the experiments with the radioactive compound may not be indicative of the manner in which the larger quantities are taken up and stored in a form available for release by tyramine.

Although the mechanisms responsible for the norepinephrine depletion in the failing heart have not been defined, chronically augmented activity of the sympathetic nervous system, which occurs in heart failure $(11,12)$, may have led to an exhaustion of the stores in the heart. The findings of a decrease of norepinephrine not only in the failing right ventricle, but also in the left ventricle and in the atria support this hypothesis. The marked reductions of tissue norepinephrine stores, which have also been demonstrated to occur in hemorrhagic shock $(29,30)$, a condition that is also accompanied by a greatly increased activity of the sympathetic nervous system (31), may be an analogous situation. The biochemical mechanism necessary for both synthesis and binding of the neurotransmitter in the terminations of sympathetic nerves within the myocardium might be comprised in the failing ventricle, or actual deterioration of the nerve endings may occur. Elevation of venous pressure, fluid accumulation, and increased aldosterone production in the absence of congestive heart failure do not appear to affect the norepinephrine stores of the heart. This was shown in the dog in which the inferior vena cava had been ligated and in which the ventricular norepinephrine concentration was within normal 
limits. The findings in the sham-operated dogs suggest that the operative procedure itself did not significantly interfere with the sympathetic innervation of the heart, since no decrease in ventricular norepinephrine occurred in these dogs. In addition, the norepinephrine depletion observed in the dog with naturally occurring chronic congestive heart failure further substantiates that this finding is related to the heart failure state per se rather than to the operative intervention or the relatively short duration of the circulatory impairment in the experimental model.

The striking reduction of norepinephrine observed in the hearts of these dogs and in the atria of patients with congestive heart failure raises the question whether sympathetic nerve function may be impaired in this condition. The concentrations of neurotransmitter are of the same order of magnitude as in animals and patients treated with pharmacologic agents that deplete norepinephrine stores and that are considered to interfere with adrenergic transmission by this mechanism (3234). It would seem possible, therefore, that the depletion in congestive heart failure could interfere with the function of the cardiac sympathetic nerves. A decrease in the sympathetic support to the myocardium might be expected to compromise the heart's performance further. Indeed, some (35), although not all, experiments have suggested that when cardiac norepinephrine stores are reduced, either by reserpine or surgical sympathectomy, to levels comparable to those observed in congestive heart failure, a decline in the contractile state of the heart muscle occurs. A more complete understanding of the mechanisms responsible for the biochemical abnormality described in this report may provide an additional approach to the clinical management of congestive heart failure.

\section{Summary}

The recent observation that myocardial norepinephrine concentration is reduced in patients with congestive heart failure suggested that a depletion of neurotransmitter store may occur in this condition. This possibility was examined in experimental congestive heart failure, which was produced in eight dogs by creation of tricuspid insufficiency and pulmonic stenosis. When sacri- ficed 6 to 8 weeks later, ascites and hepatic congestion were present in all animals. The concentration and total amount of norepinephrine in both ventricles were strikingly reduced, the latter averaging 0.15 and $0.63 \mu \mathrm{g}$ per $\mathrm{kg}$ body weight, respectively, in right and left ventricles, compared to 1.14 and $3.89 \mu \mathrm{g}$ per $\mathrm{kg}$ in control dogs. In spite of this depletion of ventricular norepinephrine, uptake and binding of a tracer dose of radioactive norepinephrine were not significantly reduced in the animals with heart failure. The effects of tyramine were studied in isolated right ventricular papillary muscle preparations. The maximal increase in contractile force produced by tyramine averaged $138 \%$ above control in muscles from normal dogs and less than $20 \%$ in muscles from dogs with heart failure. It is concluded that depletion of norepinephrine stores occurs in congestive heart failure, and it is suggested that this depletion may interfere with transmission of sympathetic nerve impulses to the heart and thereby adversely affect myocardial performance.

\section{Acknowledgments}

We acknowledge the helpful cooperation of Dr. J. O. Davis, who provided some of the animals with congestive heart failure used in this study and advice regarding the surgical aspects of the heart failure preparation, and Dr. William Roberts, who kindly reviewed the microscopic sections of liver, and the technical assistance of Miss Kathleen Daly.

\section{References}

1. Mommaerts, W. F. H. M. Heart muscle in Circulation of the Blood, A. P. Fishman and D. W. Richards, Eds. New York, Oxford University Press, 1964, p. 127.

2. Olson, R. E. Physiology of cardiac muscle in Handbook of Physiology, Section 2: Circulation, W. F. Hamilton, Ed. Washington, D. C.., American Physiology Society, 1962, vol. 1, p. 199.

3. Anzola, J., and R. F. Rushmer. Cardiac response to sympathetic stimulation. Circulat. Res. 1956, 4, 302.

4. Sarnoff, S. J., S. K. Brockman, J. P. Gilmore, R. J. Linden, and J. H. Mitchell. Regulation of ventricular contraction: Influence of cardiac sympathetic and vagal nerve stimulation on atrial and ventricular dynamics. Circulat. Res. 1960, 8, 1108.

5. Braunwald, E., C. A. Chidsey, D. C. Harrison, T. E. Gaffney, and R. L. Kahler. Studies on the func- 
tion of the adrenergic nerve endings in the heart. Circulation 1963, 28, 958.

6. Myers, J. D., and J. B. Hickam. An estimation of the hepatic blood flow and splanchnic oxygen consumption in heart failure. J. clin. Invest. 1948, 27, 620.

7. Merrill, A. J. Edema and decreased renal blood flow in patients with chronic congestive heart failure: evidence of 'forward failure' as a primary cause of edema. J. clin. Invest. 1946, 25, 389.

8. Wood, J. E., J. Litter, and R. W. Wilkins. Peripheral venoconstriction in human congestive heart failure. Circulation 1956, 13, 524.

9. Burch, G. E. Evidence for increased venous tone in chronic congestive heart failure. Arch. intern. Med. 1956, 98, 750.

10. Wood, J. E. The mechanism of increased venous pressure with exercise in congestive heart failure. J. clin. Invest. 1962, 41, 2020.

11. Tomomatsu, T., Y. Ueba, T. Matsumoto, T. Ikoma, and $\mathrm{Y}$. Kondo. Catecholamine in congestive heart failure. Jap. Heart J. 1963, 4, 13.

12. Chidsey, C. A., and A. G. Morrow. Analysis of sympathetic activity and cardiac norepinephrine stores in congestive heart failure (abstract). Clin. Res. 1964, 12, 178.

13. Chidsey, C. A., D. C. Harrison, and E. Braunwald. Augmentation of plasma norepinephrine response to exercise in patients with congestive heart failure. New Engl. J. Med. 1962, 267, 650.

14. Burch, G. E. Influence of the central nervous system on veins in man. Physiol. Rev. 1960, 40 (suppl. 4), 50.

15. Chidsey, C. A., E. Braunwald, A. G. Morrow, and D. T. Mason. Myocardial norepinephrine concentration in man: effects of reserpine and of congestive heart failure. New Engl. J. Med. 1963, 269, 653.

16. Trendelenburg, U. Supersensitivity and subsensitivity to sympathomimetic amines. Pharmacol. Rev. 1963, 15, 225.

17. Barger, A. C., B. B. Roe, and G. S. Richardson. Relation of valvular lesions and of exercise to auricular pressure, work tolerance, and to development of chronic, congestive failure in dogs. Amer. J. Physiol. 1952, 169, 384.

18. Davis, J. O., M. Trapasso, and N. A. Yankopoulus. Studies of actomyosin from cardiac muscle of dogs with experimental congestive heart failure. Circulat. Res. 1959, 7, 957.

19. Davis, J. O., and D. S. Howell. Mechanisms of fluid and electrolyte retention in experimental preparations in dogs. II. With thoracic inferior vena cava constriction. Circulat. Res. 1953, 1, 171.
20. Crout, J. R., C. R. Creveling, and S. Udenfriend. Norepinephrine metabolism in rat brain and heart. J. Pharmacol. exp. Ther. 1961, 132, 269.

21. Bertler, A., A. Carlsson, and E. Rosengren. A method for the fluorometric determination of adrenaline and noradrenaline in tissues. Acta physiol. scand. 1958, 44, 273.

22. Von Euler, U. S., and F. Lishajko. Improved technique for the fluorometric estimation of catecholamines. Acta physiol. scand. 1961, 51, 348.

23. Bray, G. A. A simple efficient liquid scintillator for counting aqueous solutions in a liquid scintillation counter. Analyt. Biochem. 1960, 1, 279.

24. Sonnenblick, E. H. Force-velocity relations in mammalian heart muscle. Amer. J. Physiol. 1962, 202, 931.

25. Spann, J., C. A. Chidsey, and E. Braunwald. Reduction of norepinephrine stores in experimental heart failure. Science 1964, 145, 1439.

26. Crout, J. R., A. J. Muskus, and U. Trendelenburg. Effect of tyramine on isolated guinea-pig atria in relation to their noradrenaline stores. Brit. J. Pharmacol. 1962, 18, 600.

27. Burn, J. H., and M. J. Rand. The effect of precursors of noradrenaline on the response to tyramine and sympathetic stimulation. Brit. J. Pharmacol. 1960, 15, 47 .

28. Gaffney, T. E., D. H. Morrow, and C. A. Chidsey. The role of myocardial catecholamines in the response to tyramine. J. Pharmacol. exp. Ther. 1962, 137, 301.

29. Coleman, B., and V. V. Glaviano. Tissue levels of norepinephrine and epinephrine in hemorrhagic shock. Science 1962, 139, 54.

30. Hift, H., and H. A. Campos. Changes in the subcellular distribution of cardiac catecholamines in dogs dying in irreversible hæmorrhagic shock. Nature (Lond.) 1962, 196, 678.

31. Neil, E. Reflex Mechanisms and the Central Nervous System in Shock: Pathogenesis and Therapy. New York, Academic Press, 1962, p. 172.

32. Trendelenburg, U., and J. S. Gravenstein. Effect of reserpine pretreatment on stimulation of accelerans nerve of the dog. Science 1958, 128, 901.

33. Gaffney, T. E., C. A. Chidsey, and E. Braunwald. Study of the relationship between neurotransmitter store and adrenergic nerve block induced by reserpine and guanethidine. Circulat. Res. 1963, 12, 264.

34. Day, M. D., and M. J. Rand. Some observations on the pharmacology of $\alpha$-methyldopa. Brit. J. Pharmacol. 1964, 22, 72.

35. Lee, W. C., and F. E. Shideman. Role of myocardial catecholamines in cardiac contractility. Science 1959, 129, 967. 